\title{
Women in Leadership: Profiles in Courage, Empathy, and Service
}

\author{
Dr. Arthur M. Baldonado, PhD* \\ Columbia Southern University, 21982 University Ln, Orange Beach, AL 36561 \\ *Corresponding Author: Dr. Arthur M. Baldonado, PhD, Columbia Southern University, 21982 \\ University Ln, Orange Beach, AL 36561

\begin{abstract}
Effective leaders transformed our workplace to the future. Women have shown extraordinary leadership throughout history. This article depicts lessons that can be extracted from the lives of successful female business leaders in history-Katharine Graham, Mary Barra, and Sheryl Sandberg. These leaders persevered in achieving their goals, have great confidence in themselves, and have great team surrounding them.
\end{abstract}

Keywords: Women, Leadership, Transformational

\section{INTRODUCTION}

Business leaders have often been dominated by men. The field of leadership studies have frequently focused on business leaders like John D. Rockefeller, Henry Ford, Warren Buffett, and Jack Welch. While there is much to be learned from the lessons of these great male business leaders; however, when it comes to developing female leaders in the field of business, it seems logical to find lessons from the lives of successful female, business leaders today. Women comprised nearly $40 \%$ of all managers in the workforce (BLS Reports, 2019).

Katharine Graham, Mary Barra, and Sheryl Sandberg are the business leaders selected to extract lessons from in this article. These leaders come from unique background and are among the most successful entrepreneurs today. This author connected leadership lessons obtained from these three prominent female leaders with current leadership theory.

\section{LEADERS' BACKGROUND}

Katharine Graham was born in 1917 in New York City and grew up in a wealthy household where the family purchased the Washington Post newspaper. Graham completed her undergraduate degree at the University of Chicago, and she later moved to San Francisco and worked as a reporter. She married a Supreme Court clerk, Phil Graham who became Washington Post's publisher. Graham took over the helm of Washington Post when her husband died. She guided the Washington Post newspaper to national prominence throughout the Pentagon Papers and Watergate scandal. She was the first female Fortune 500 CEO. Graham died in 2001 (Biography, 2019).

Mary Barra was born in 1961 in Michigan to parents of Finnish descent and her father working as a die maker. Barra completed her bachelor's degree at Kettering University and MBA at Stanford University. In 1985, Barra married her husband Anthony Barra. Barra became General Motors (GM) CEO in 2014, becoming the first woman in history to head of the "Big Three" American automakers. She took over the company during the "Switchgate" scandal-a decadelong cover-up involving faulty vehicle ignition switches in several car models. Several magazines cited Barra on their influential listings such as "100 Most Influential People" and "Word's 100 Most Powerful Women", and "50 Most Powerful Women in Business" (Encyclopedia Brittanica, 2019).

Sheryl Sandberg was born in 1969 in Washington D.C. but her family moved to Florida when she was 2-years old. Sandberg completed her undergraduate degree and MBA at Harvard University graduating with honors/distinctions. She worked in the U.S. Department of Treasury during the Clinton administration and worked for Google for seven years. Sandberg is currently Facebook's chief operating officer where she became the first female member of the company's board of International Journal of Managerial Studies and Research (IJMSR) 
directors. She was married to Dave Goldberg, a Yahoo! Executive and have two children together. Sandberg received various accolades such as Time's list of "100 Most influential People in the World" and Forbes list of "Most Powerful Women" (Biography, 2019).

\section{LEADERS' BEHAVIOR}

Katharine Graham has a humble yet firm leadership style. Thrust into the leadership role after the death of her husband, she was firm and dedicated during two of the greatest moments in American journalism - 1971 Pentagon Papers and 1972 Watergate story. Graham inspires others through her calm yet firm strength while maintaining compassion and understanding (Tylor, 2012). During Graham's tenure, Washington Post has grown in revenues from $\$ 84$ billion in 1963 to $\$ 1.4$ billion in 1993 while stock rose 30 times in value. Graham was awarded the Pulitzer Prize for her memoir in 1998 (Biography, 2019).

Mary Barra exhibits an inclusive leadership style. With over 33 years of managerial experience at GM, Barra became the first female CEO of a major automaker in 2014. Barra is known for her collaborative approach conducting town hall meetings to seek input on projects. Moreover, she seeks tension in a constructive way while making the final decision at the end. Barra received praises for her listening skills and approachability, and thus creating an inclusive environment where workers can voice their opinions. Safety, innovation and technology have been the cornerstone of Barra's vision for GM. Consequently, GM ranked \#1 on the 2018 Global Report on General Equality (IndustryWeek, 2014)

Sheryl Sandberg is an engaged and inquisitive leader. Sandberg is known for asking smart questions and encouraging debates among employees. Asking what employees think is vital to getting honest feedback and information. At Facebook, Sandberg visited people's desks, introduced herself, asked questions, and listened to employees. Sandberg believes in team effort/spirit propelling her to write a book entitled "Lean In" which launched Lean In movement. Experts contend Sandberg is responsible for Facebook's stunning success in handling logistics such as human resources and advertising. Facebook has over 1 billion users becoming one of the most top regarded companies in the world (Doyle, 2017).

\section{ANALYSIS OF LEADERS' BEHAVIOR}

Leadership theories seek to explain why and how individuals become leaders. Prominent leadership theories include Great man, Trait, Contingency, Situational, Behavioral, Participative, Management, Relationship theories. This author believes all three leaders exhibited qualities found in a transformational style of leadership - encourages, inspires, and motivates employees to innovate and create change and growth in organizations (Yukl, 2013).

There are more similarities than differences among these leaders. All these leaders have the following in common:

- Faced and overcome challenges during their leadership tenure

- Sought employees' feedback and input

- Exhibited ambition and passion for their work

- Demonstrated desire to learn and ask questions

- Showed collaboration in working with others

Leadership is all about influencing others to action. All three leaders--Graham (Watergate/Pentagon Papers scandal), Barra (Switchgate scandal), and Sandberg (Facebook expansion) --overcame challenges in their professional careers. Moreover, these women have shown great collaboration skills and are eager learners. Finally, Graham, Barra, and Sandberg are all passionate about their work's success, and showed transformational leadership by encouraging, inspiring, and motivating others to reach maximum potential.

\section{CONCLUSION}

Women have made progress in management/leadership positions; however, they continue to be underrepresented in leadership roles in organizations (BLS Reports, 2019). This article examines the lives of three prominent leaders - Katharine Graham, Mary Barra, and Sheryl Sandberg. These women are trailblazers transforming their organizations to be leaders in their industry. 


\section{REFERENCES}

[1] Avolio, B. (2007). Promoting more integrative strategies for leadership theory-building. American Psychologist, 62(1), 25.

[2] Biography. (2019). Katharine Graham. Retrieved from https://www.biography.com/business-figure/ katharine-graham

[3] BLS Reports. (2019). Women in the labor force: A databook. Retrieved from https://www.bls.gov/opub/ted/2016/39-percent-of-managers-in-2015-were-women.htm

[4] Biography. (2019). Sheryl Sandberg. Retrieved from https://www.biography.com/business-figure/sherylsandberg

[5] Carpenter, M. A., \& Sanders, W. G. (2009). Strategic management (2nd). Upper Saddle River, NJ: Pearson Prentice Hall.

[6] Dobbs, K., Gordon, J., Lee, C. \& Stamps, D. (1999). Leadership theories: A top-10 list. Training, 36(10), 26-27.

[7] Doyle, S. (2017). What every boss can learn about leadership from Sheryl Sandberg at Facebook. Retrieved from https://www.inc.com/shawn-doyle/what-every-boss-can-learn-about-leadership-fromsh.html

[8] Elsbach, K. D., Kayes, A., \& Kayes, D. C. (2016). Contemporary organizational behvior: From ideas to action. Upper Saddle River, NJ: Prentice Hall.

[9] Encyclopedia Brittanica. (2019). Mary Barra. Retrieved from https://www.Britannica.com/biography /Mary-Barra

[10] Goleman, D., Boyatzis, R., \& McKee, A. (2002). Primal leadership: Realizing the power of emotional intelligence. Boston, MA: Harvard Business School Press.

[11] Helft, M. (2014). The most ambitious CEO in the universe. Fortune, 170(8), 140-149.

[12] Hill, C. W. L. (2011). Global business today (7th ed.). New York: McGraw-Hill Publishing.

[13] IndustryWeek. (2014). Did Mary Barra's inclusive leadership style propel her to the top? Retrieed from https://www.industryweek.com/leadership/companies-executives/article/21962100/did-mary-barrasinclusive-leadership-style-propel-her-to-the-top

[14] Silva, A. (2014). What can we learn from great business leaders? Journal of Leadership Studies, 8(3), 5256.

[15] Tylor, J. (2012). Leadership lessons from Katherine Graham. Retrieved from http://cronkitehhh.jmc.asu. edu/blog/2012/04/leadership-lessons-from-katharine-graham/

[16] Wagner, J. A., \& Hollenbeck, J. R. (2001). Organizational behavior: Securing a competitive advantage. Forth Worth, TX: Harcourt College Publishers.

[17] Yukl, G. (2013). Leadership in organizations (8th ed.). Upper Saddle River, NJ: Prentice Hall.

\section{Author's Biography}

Dr. Baldonado, has taught at various universities such as Ashford University, University of Phoenix, Ultimate Medical Academy, and Columbia Southern University. His areas of expertise include human resources, work motivation and diversity, business administration, and management. Dr. Baldonado has over 10 years of human resources experience and has published in his field.

Citation: Dr. Arthur M. Baldonado, PhD. "Women in Leadership: Profiles in Courage, Empathy, and Service" International Journal of Managerial Studies and Research (IJMSR), vol 8, no. 1, 2020, pp. 57-59. doi: http://dx.doi.org/10.20431/23 49-0349.0801006.

Copyright: (C) 2020 Authors. This is an open-access article distributed under the terms of the Creative Commons Attribution License, which permits unrestricted use, distribution, and reproduction in any medium, provided the original author and source are credited. 